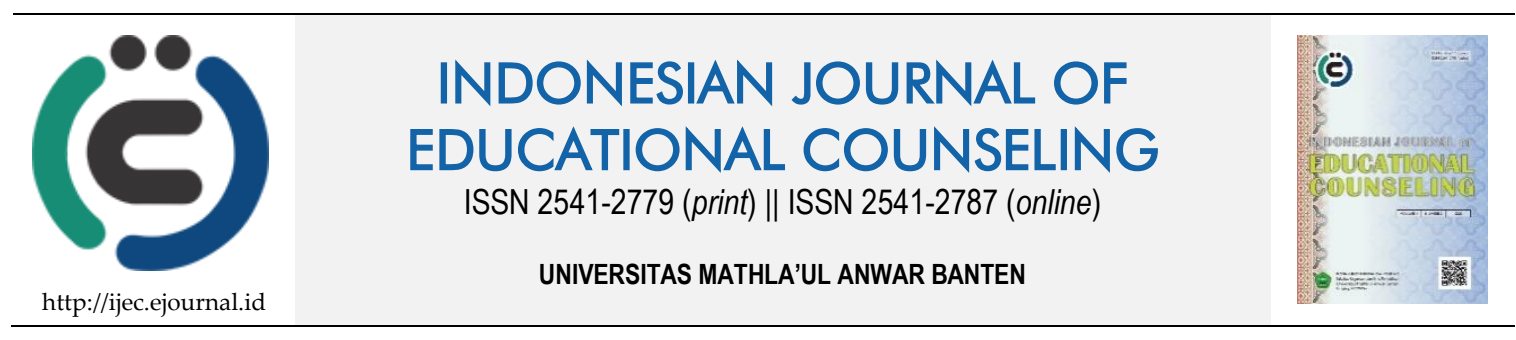

Research Based Article

\title{
Pengembangan Perilaku Asertif dengan Teknik Sosiodrama untuk Mencegah Perilaku Bullying
}

\author{
Susilo Rahardjo ${ }^{1}$, Edris Zamroni², Sumarni ${ }^{3}$, Derta Prihastuti ${ }^{4}$ \\ 1, 2, 3 Universitas Muria Kudus, Indonesia \\ ${ }^{4}$ SMP 2 Bae Kudus, Indonesia
}

\begin{tabular}{ll}
\hline Article History & ABSTRACT \\
\hline $\begin{array}{l}\text { Received: } 22.04 .2020 \\
\text { Received in revised form: }\end{array}$ & DEVELOPING ASSERTIVE BEHAVIOR WITH SOCIODRAMA \\
02.05 .2020 & TECHNIQUES TO PREVENT BULLYING BEHAVIOR. The influence of mass \\
Accepted: 25.06 .2020 & media has an impact on the spread of bullying behavior including in the school \\
Available online: 28.07 .2020 & environment. The negative impact of student bullying becomes depressed, \\
& performance decreases, and can ultimately lead to students dropping out of \\
& school. Therefore it needs to be prevented so that it does not expand, and the \\
& school becomes a friendly and pleasant environment. The purpose of this \\
& research is to provide students with an understanding of bullying behavior that \\
& can occur at school, and students can prevent it by behaving assertively. One \\
& way to prevent bullying is to develop assertive student behavior. Through \\
& PTBK students are trained to prevent bullying behavior with the guidance of \\
& sociodrama techniques. The reader can develop a model of preventing bullying \\
& behavior in the same way or in other ways, so that the school becomes a \\
& pleasant and friendly environment.
\end{tabular}

KEYWORDS: Assertive Behavior, Bullying Behavior, Sociodrama Techniques.

DOI: $10.30653 / 001.202042 .131$

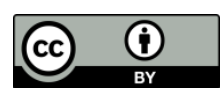

This is an open access article distributed under the terms of the Creative Commons Attribution 4.0 International License, which permits unrestricted use, distribution, and reproduction in any medium, provided the original work is properly cited. (c) 2020 Susilo Rahardjo, Edris Zamroni, Sumarni, Derta Prihastuti.

\section{PENDAHULUAN}

Pada masa terakhir ini hampir setiap hari kita sering disuguhi tontonan kekerasan. Seakan-akan kekerasan sudah menjadi bagian dari kehidupan dan budaya masyarakat. Tanpa terkecuali kekerasan yang terjadi di sekolah dan dilakukan oleh pelajar. Pembentukan kepribadian yang kurang baik pada remaja dapat berdampak pada terjadinya masalah di kalangan remaja, salah satunya adalah masalah bullying.

Bullying dapat kita lihat di televisi pada segmen berita, film, dan acara-acara lain yang langsung maupun tidak langsung, sadar atau tidak sadar, acara-acara itu memuat bullying. Demikian pula melalui media sosial WhatsApp, Facebook, Twitter, Instagram. Mengingat dampak negatif bullying konselor perlu memberikan pelayanan bimbingan dan konseling, dan layanan yang diberikan dapat berfungsi pencegahan. Melalui layanan

\footnotetext{
${ }^{2}$ Corresponding author's address: Program Studi Bimbingan dan Konseling, FKIP Universitas Muria Kudus; Gedung N.I.3. Kampus
} UMK Gondangmanis Bae Kudus, Indonesia. Email: edris.zamroni@umk.ac.id 
bimbingan klasikal dengan teknik sosiodrama siswa dilatih mengembangkan perilaku asertif untuk mencegah bullying di sekolah.

Bullying berasal dari kata bully, yaitu suatu kata yang mengacu pada pengertian adanya ancaman yang dilakukan seseorang ataupun kelompok terhadap orang lain atau kelompok lain (yang umumnya lebih lemah atau lebih rendah dari pelaku), yang menimbulkan gangguan psikis bagi korbannya berupa stress (depresi, ketakutan, rendah diri, kecemasan, dan lain-lain. Bentuk kekerasan tidak hanya berupa fisik namun juga secara verbal. Bullying merupakan suatu bentuk perilaku agresif yang diwujudkan dengan perlakuan secara tidak sopan dan penggunaan kekerasan atau paksaan untuk mempengaruhi orang lain, yang dilakukan secara berulang atau berpotensi untuk terulang.

Menurut Coloroso (2006, p. 44), bullying adalah tindakan bermusuhan yang dilakukan secara sadar dan disengaja yang bertujuan untuk menyakiti, seperti menakuti melalui ancaman, agresi, menimbulkan teror sebagi tindakan yang direncanakan maupun spontan, bersifat nyata atau hampir tidak terlihat, di hadapan seseorang atau di belakang seseorang, mudah untuk diidentifikasi atau terselubung di balik persahabatan, dilakukan oleh seorang anak atau kelompok. Beberapa bullyer (pelaku bullying) melakukan bullying karena tidak mengerti apa yang dilakukannya adalah salah. Beberapa yang lain melakukannya dengan sengaja karena terinspirasi dan meniru apa yang mereka lihat di rumah maupun dari tayangan media elektronik seperti TV/film, atau media sosial yang tersebar melalui handphone.

Bullying dapat terjadi di mana manusia berinteraksi satu sama lain, seperti: sekolah, keluarga, tempat kerja, rumah, dan lingkungan yang lebih luas. Fenomena bullying masih terus terjadi di kalangan remaja dan terjadi di wilayah sekolah. Berdasarkan hasil survey Yayasan SEJIWA tahun 2008, menyebutkan 94,9\% bullying terjadi di sekolah. Hasil survey yang dilakukan Latitudenews (2012) menunjukkan bahwa Indonesia sebagai negara berperingkat kedua dari 40 negara yang marak kasus bullying.

Sekretaris Jenderal Komnas PA, Samsul Ridwan menyebut adanya peningkatan laporan atau pengaduan yang diterima Divisi Pengaduan dan Advokasi Komnas Anak. Untuk jumlah pengaduan yang masuk, peningkatannya mencapai $98 \%$ pada tahun 2011, yaitu 2.386 pengaduan dari 1.234 laporan pada tahun 2010. Hal ini tentu memprihatinkan. Sekolah yang seharusnya menjadi tempat yang menyenangkan berubah menjadi tempat yang mengerikan (Warnaningrum \& Na'imah, 2016).

Sudah barang tentu semua stake holder pendidikan tidak bisa berdiam diri melihat realitas bahwa Indonesia merupakan negara yang sangat tinggi tingkat bullyingnya. Harus segera dilakukan upaya pencegahan dan pengatasan masalah bullying, salah satunya melalui pelayanan bimbingan dan konseling. Karunia (2018) mengidentifikasi, perilaku bullying terjadi karena: ada kesenjangan power/kekuatan antara pelaku dan korbannya, memiliki pengalaman masa lalu yang sama, dan pola asuh orang tua.Puspitasari (2017) menyebutkan ada tujuh penyebab anak melakukan tindakan bullying, yaitu kurang perhatian, ingin berkuasa, pola asuh dalam keluarga, ekspos kekerasan di media, pernah jadi korban kekerasan, riwayat berkelahi, faktor pubertas dan krisis identitas. Sementara itu Warnaningrum dan Na'imah (2016) menyatakan bahwa salah satu sebab terjadinya bullying karena peserta didik berada pada masa transisi perkembangan dari masa kanak-kanank ke masa remaja. 
Perilaku bullying yang banyak terjadi di sekolah sebagaimana Komnas PA, harus diperhatikan oleh semua pihak yang terkait, karena dampak yang terjadi bisa sangat serius. Karunia (2018) menyatakan bahwa dampak bullying sangat beragam mulai dari dampak yang sangat ringan seperti takut datang ke sekolah, prestasi sekolah menurun hingga sangat parah, suicide misalnya. Keberagaman itu disebabkan oleh berbagai faktor, antara lain social support yang diterima dari orang tua maupun lingkungan, bentuk bullying yang diterima anak, maupun karakteristik anak itu sendiri.

Mencermati dampak perilaku bullyingbagi korban, sudah barang tentu perlu dilakukan upaya-upaya mengatasinya. Kusumawardhani (2015) menyebutkan, langkah awal yang bisa dilakukan orang tua bila tahu anaknya dibully: (1) Mendengarkan cerita/keluhan anak, (2) Membangun rasa percaya diri, (3) Bermain peran, (4) Hubungi pihak sekolah. Karunia (2018) menyatakan bahwa "perilaku bullying bisa dihilangkan dan pastinya penghilangan bullying tersebut memerlukan kerjasama berbagai pihak, terutama untuk remaja yang tidak berada dalam perlindungan/tanggung jawab institusi tertentu. Karena itu, kita membutuhkan kolaborasi yang baik dari berbagai pihak, mulai dari orang tua, sekolah dan masyarakat (organisasi pemuda, organisasi keagamaan, institusi pendidikan) sehingga bisa menjadi panutan yang memberikan petunjuk sekaligus menyeleksi mana kegiatan yang positif yang harus dikembangkan, dan mana kegiatan yang negatif dan wajib diberhentikan."

Linda (2019) memberikan sepuluh cara yang efektif menghadapi bully yaitu: (1) Jangan memberikan reaksi apapun, (2) Tunjukkan bahwa kamu tidak takut, (3) Berbicara dengan orang lain, (4) Hindari si tukang bully, (5) Jadi lebih baik dari mereka, (6) Kumpulkan bukti bully dan laporkan ke pihak yang berwenang, (7) Belajar bela diri, (8) Cari dukungan orang lain, (9) Ikut konseling, (10) Jadi berani melawan bully.

Beberapa penelitian terakhir menunjukkan adanya upaya untuk mengatasi perilaku bullying di kalangan pelajar. Salah satunya dilakukan oleh Sari (2016), yaitu melatih siswa mengembangkan perilaku asertif untuk mencegah perilaku bullying siswa sekolah menengah dengan teknik sosiodrama. Penulis bersama dengan dosen Program Studi Bimbingan dan Konseling FKIP Universitas Muria Kudus dan Guru BK SMP 2 Bae Kudus melakukan Penelitian Tindakan Bimbingan dan Konseling (PTBK) sebagaimana yang dilakukan oleh Sari (2016). Perilaku asertif dilatihkan kepada siswa melalui layanan bimbingan klasikal dan kelompok dengan teknik sosiodrama.

Sekolah merupakan lingkungan yang sengaja diciptakan untuk membina anak-anak khususnya untuk mengembangkan kemampuan dan keterampilan sebagai bekal hidupnya di kemudian hari sebagai pribadi yang mandiri. Berkaitan dengan hal itu Depdikbud (2007) menetapkan bahwa setiap peserta didik lulusan SMP hendaknya memenuhi kompetensi yang digariskan dalam Standar Kompetensi Kemandirian Peserta Didik (SKKPD). SKKPD pada satuan SMP mencakup 10 aspek perkembangan, yaitu: landasan hidup religius, landasan perilaku etis, kematangan emosi, kematangan intelektual, kesadaran tanggungjawab sosial, kesadaran gender, pengembangan pribadi, perilaku kewirausahaan/kemandirian perilaku ekonomis, wawasan dan kesiapan karir, dan kematangan hubungan dengan teman sebaya.

Siswa yangmengikuti proses pendidikan untuk mengembangkan kemampuan dan keterampilannya dalam bentuk kompetensi kemandirian sering mengalami gangguan dari luar, salah satunya bullying. Perilaku bullying yang dialami oleh seorang siswa dapat mengganggu perkembangannya dalam mencapai kompetensi dan kemandiriannya. 
Salah satu faktor adanya perilaku bullying di kalangan remaja yang banyak terjadi di lingkungan sekolah adalah karena rendahnya keterampilan asertif yang dimiliki siswa. Selain itu, siswa yang keterampilan asertifnya rendah akan mengalami masalah dan cenderung mudah terkena pengaruh teman sebaya. Masalah tersebut dapat terjadi karena rendahnya kecakapan emosional siswa, yang meliputi kemampuan ekspresi emosional seperti marah, benci, serta emosi negatif lainnya.

Menurut Strorey, Slaby, dan Adler (2013) bahwa anak-anak atau remaja dapat melindungi dirinya dari tindakan bullying dengan bersikap asertif. Bersikap asertif tidak memprovokasi untuk mengintimidasi atau membalas, individu yang asertif memiliki rasa percaya diri dan rasa kontrol yang dapat mencegah perilaku bullying. Siswa yang tidak mampu berperilaku asertif akan sulit mengatakan "tidak" (menolak) terhadap ajakan teman yang cenderung ke arah negatif. Dari ketidakmampuan siswa menolak ajakan teman yang cenderung negatif ini, maka muncullah perilaku negatif seperti bullying di sekolah yang dilakukan oleh siswa.

Lange dan Jackubowsi (1978) menegaskan bahwa perilaku asertif adalah mempertahankan hak-hak individu dan mengekspresikan apa yang ia yakini, rasakan serta inginkan secara langsung dan jujur dengan cara yang sesuai serta menunjukkan penghargaan terhadap hak-hak orang lain. Asertif sendiri dimaknai sebagai kemampuan seseorang menyatakan diri, pandangan-pandangan dalam dirinya, keinginan dan perasaannya secara langsung, spontan, bebas, dan jujur tanpa merugikan diri sendiri dan melanggar hak-hak orang lain.

Abdillah (2015) menyatakan bahwa asertif dilakukan demi kebaikan orang tersebut. Ini untuk menghindari keletihan emosional akibat selalu menyembunyikan perasaan dan pikiran. Sehingga keinginan kita pun tidak akan pernah tercapai karena tak terungkap. Sari (2016) merumuskan manfaat berperilaku asertif sebagai berikut: bebas dari konflik, meningkatkan percaya diri, membantu mengelola stres, hidup yang tidak terikat dan bebas.

Dengan demikian manfaat perilaku asertif adalah membebaskan seseorang dari tekanan perasaan, dapat mengekspresikan kata "tidak" tanpa dibebani rasa bersalah dan perasaan negatif lainnya. Perilaku asertif pada diri seseorang tidak muncul begitu saja, namun perlu latihan. Karena lingkungan dan budaya di mana seseorang tinggal dan beraktivitas memberikan kontribusi pada rendahnya perilaku asertif. Breitman \& Hatch (2001) menekankan pentingnya "mengatakan 'tidak' tanpa merasa bersalah" sebagai bentuk perilaku asertif. Meskipun demikian berkata "tidak" memerlukan latihan dimulai dari lingkungan orang terdekat yang akrab sampai meluas ke lingkungan kerja yang penuh tekanan.

Sekarang ini beberapa sekolah mulai menyadari bahaya perilaku bullying yang beberapa di antaranya sudah diekspos di media televisi dan media sosial terutama whatsapp. Oleh karena itu pencegahan terhadap perilaku bullying dilakukan konselor sebagai upaya menuju sekolah yang aman dan menyenangkan.

\section{METODE}

Penelitian ini merupakan penelitian tindakan yang oleh Bogdan dan Biklen (1982) dimaknai sebagai pengumpulan informasi yang sistematik yang dirancang untuk menghasilkan perubahan sosial. Secara spesifik penelitian tindakan ini dilaksanakan dalam kegiatan bimbingan dan konseling (PTBK). Tadjri (2014) memaknai PTBK sebagai 
penelitian kolaboratif yang dilakukan konselor berdasarkan refleksi diri dengan tujuan untuk memperbaiki mutu layanan BK agar kesejahteraan mental siswa meningkat. Penelitian tindakan bimbingan dan konseling ini menggunakan ancangan deskriptif/interpretif. Secara harfiah deskriptif/interpretif menunjuk pada uraian (deskriptif) data untuk ditafsirkan. Sifat penafsiran (interpretif) terkandung mulai dari saat pengumpulan fenomena atau data, penyajian dan analisis data sampai pada upaya pelaporan penelitian (Mappiare-AT, 2013).

Sugiyono (2014) menegaskan bahwa dalam penelitian deskriptif analisis data dari kumpulan data yang dihimpun dideskripsikan sebagaimana adanya data tersebut tanpa harus membuat kesimpulan umum atau generalisasi. Selanjutnya Salim dan Haidir (2019) menjelaskan bahwa, penelitian deskriptif memusatkan perhatian pada masalah-masalah actual sebagaimana adanya pada saat penelitian berlangsung. Di sini peneliti berusaha mendeskripsikan persitiwa dan kejadian yang menjadi pusat perhatian tanpa memberikan perlakuan khusus terhadap peristiwa tersebut. Analisis data dilakukan dengan memperkaya informasi, mencari hubungan, membandingkan, menemukan pola dasar data aslinya (tidak ditransformasikan dalam bentuk angka). Hasil analisis data berupa pemaparan mengenai yang diteliti disajikan dalam bentuk uraian naratif.

Dengan demikian, dapat disimpulkan bahwa penelitian deskriptif adalah penelitian yang berusaha menggambarkan kejadian, bukan untuk mencari atau menguji teori, yang berlangsung pada saat penelitian dilaksanakan. Semua data dalam penelitian ini dipaparkan secara deskriptif atau naratif.

Prosedur penelitian tindakan bimbingan dan konseling (PTBK) dilakukan melalui tahapan pengumpulan data awal, siklus I, Siklus II dan simpulan. Data awal diperoleh dari Angket Kemandirian Peserta Didik (AKPD), di mana 20 dari 30 siswa member tanda cek $(\sqrt{ })$ pada item "Saya belum tahu tentang bullying dan cara mensikapinya". Peneliti melakukan diskusi untuk mencegah perilaku bullying pada siswa kelas 8A. Pemecahan masalah menggunakan bimbingan klasikal dengan teknik sosiodrama untuk mencegah perilaku bullying.

Siklus I dan Siklus II dilaksanakan melalui perencanaan, tindakan, observasi dan refleksi. Materi bimbingan klasikal dengan teknik sosiodrama bersumber dari Sari (2016). Pada siklus I materi bimbingan klasikal meliputi: (1) Konsep Dasar Perilaku Asertif, (2) Mengekspresikan Perasaan, (3) Mengungkapkan Pikiran dan Pendapat Pribadi, (4) Mengatakan Tidak. Pada siklus II, materinya: (5) Mengembangkan Kesadaran Diri, (6) Memperjuangkan Hak-hak Pribadi, (7) Memberi Arahan, (8) Mengatasi Konflik.

Instrumen penilaian dan format penilaian mengadopsi dari Sari (2016). Ada 50 item soal evaluasi dengan pilihan jawaban: Selalu (SL), Sering (SR), Kadang-kadang (KD), Tidak Pernah (TP). Setiap pilihan jawaban diberi skor $\mathrm{SL}=4, \mathrm{SR}=3, \mathrm{KD}=2, \mathrm{TP}=1$. Semua skor jawaban yang telah dikerjakan siswa dijumlah dengan rumus:

$$
\text { Skor }=\frac{\text { Jumlah skor }}{\text { Jumlah soalx } 4} \times 100 \%
$$

Dari hasil yang diperoleh, selanjutnya peneliti melakukan analisis dengan mencocokkan jumlah skor akhir dengan kriteria skala keterampilan asertif siswa sebagaimana ditampilkan dalam Tabel 1. 
Tabel 1. Interpretasi Keterampilan Asertif Dengan Teknik Sosiodrama Untuk Mencegah Perilaku Bullying Siswa

\begin{tabular}{lll}
\hline Persentase & Klasifikasi & Interpretasi \\
\hline $82 \%-100 \%$ & Sangat Tinggi & Berpotensi sangat kecil melakukan bullying \\
\hline $63 \%-81 \%$ & Tinggi & Berpotensi kecil melakukan bullying \\
\hline $44 \%-62 \%$ & Rendah & Berpotensi besar melakukan bullying \\
\hline $25 \%-43 \%$ & Sangat Rendah & Berpotensi sangat besar melakukan bullying \\
\hline
\end{tabular}

\section{HASIL DAN PEMBAHASAN}

Kegiatan PTBK diawali dengan need assessment dengan menggunakan Angket Kemandirian Peserta Didik (AKPD) untuk mengetahui kecenderungan kebutuhan siswa yang kemungkinan menyebabkan terjadinya masalah. AKPD ini merupakan instrumen dengan pendekatan tujuan bidang layanan (pribadi, sosial, belajar dan karir), berupa angket. Instrumen AKPD tersebut dipilih sesuai dengan kebutuhan kegiatan perencanaan program bimbingan dan konseling (Kementerian Pendidikan dan Kebudayaan, 2016). Identifikasi kebutuhan siswa ini berfungsi pencegahan.

Berdasarkan hasil AKPD di mana 20 dari 30 siswa belum memahami bullying dan cara bersikap terhadap perilaku bullying. Skor AKPD yang diperoleh item ini 2,96\% dengan prioritas Tinggi, maknanya perlu prioritas penanganan masalah. Dengan demikian peneliti menetapkan bullying sebagai tema PTBK. Penelitian tindakan terhadap subjek penelitian dilakukan melalui layanan bimbingan klasikal dengan teknik sosiodrama.

Data penelitian seperti pada Tabel 2 diperoleh dalam tiga tahap: pra siklus, siklus I dan Siklus II. Pra siklus untuk memperoleh data awal sebelum ada perlakuan (tindakan), jumlah skor hasil instrumen evaluasi Skala Perilaku Asertif sebanyak 59.72\%. Setelah proses tindakan selama empat pertemuan pada siklus I subjek penelitian mengerjakan instrumen evaluasi dan memperoleh jumlah skor $67.03 \%$. Evaluasi terakhir dilaksanakan setelah siklus II selesai dengan empat pertemuan, jumlah skor yang diperoleh $72.15 \%$ ).

Tabel 2. Peningkatan Perilaku Asertif Siswa

\begin{tabular}{lllll}
\hline Kegiatan & Jumlah skor & Pembagi & x 100\% & \% Hasil akhir \\
\hline Prasiklus & 3,501 & 200 & 100 & 17.505 \\
\hline Siklus 1 & 3,595 & 200 & 100 & 17.975 \\
\hline Sikulis 2 & 3,970 & 200 & 100 & 19.85 \\
\hline
\end{tabular}

Berdasarkan skor yang diperoleh maka bisa diidentifikasi bahwa:

1) Sebelum dilakukan tindakan perilaku bullying responden berada pada kualifikasi Rendah $(59.72 \%)$, artinya siswa di kelas tersebut memiliki potensi besar untuk melakukan bullying.

2) Setelah tindakan yang dilakukan pada siklus I selama empat pertemuan, ada peningkatan pemahaman terhadap perilaku bullying di mana skor yang diperoleh dari evaluasi sebesar $67.03 \%$ (Tinggi). Skor ini menunjukkan bahwa responden secara klasikal sudah meningkat perilakunya menjadi berpotensi kecil melakukan bullying. Demikian pula setelah siklus II, hasil evaluasi menunjukkan peningkatan skor menjadi $72.15 \%$ (Tinggi). 
Secara kualitatif, peneliti melihat beberapa perubahan pada pertemuan pertama peserta didik mengikuti kegiatan dengan penuh antusias dan peserta didik melakukan gerakan mengikuti video ice breaking. Pada pertemuan kedua peserta didik cenderung malu untuk menjadi pemeran. Mereka harus ditunjuk oleh konselor dan konflik antar pemain sosiodrama terlalu datar, mereka belum bisa lepas untuk berekspresi. Pada pertemuan ketiga saat penentuan pemain, peserta didik belum berinisiatif pengajuan diri. Mereka masih terlihat canggung dalam memerankan peran sesuai dengan adegan-adegan di synopsis. Pada pertemuan keempat adegan ke-3 cukup mencerminkan sinopsis soosiodrama yang direncanakan. Pemeran Guru BK telah mencerminkan tugasnya dengan baik.

Pertemuan kelima, peserta didik cenderung pasif, sehingga konselor harus memilih dan menunjuk masing-masing pemeran yang ada dalam sinopsis sosiodrama dan semua pemeran sosiodrama tidak menunjukkan kesungguhan bermain. Pada pertemuan keenam semua adegan berjalan dengan baik. Pada pertemuan ketujuh siswa belum menunjukkan inisiatif mau menjadi pemeran dan konflik kelompok dengan Lucky berjalan sesuai rencana adegan. Pada pertemuan kedelapan sosiodrama ini lebih baik dari pada sosiodrama pada pertemuan ketujuh dan sosiodrama ulangan dengan pemain yang lain lebih bagus dibandingkan yang pertama. Semua pemain telah menunjukkan perannya dengan baik.

\section{SIMPULAN}

Secara umum penelitian ini mampu meningkatkan perilaku asertif siswa terhadap bullying. Mengajak siswa SMP memahami materi layanan dengan cara bermain sosiodrama, memerlukan pendampingan khusus. Karena mereka pada umumnya masih terbatas pemahamannya dalam pengetahuan dan keterampilan mencerna isi sinopsis dan adegan sosiodrama. Dengan sering melakukan kegiatan, keterampilan dan pemahaman mereka dapat meningkat. Meskipun ada peningkatan pemahaman siswa dalam mencegah perilaku bullying dengan teknik sosiodrama, perubahan skor hasil evaluasi dari pra siklus, siklus I dan siklus II nampaknya kurang bermakna.

\section{REFERENSI}

Abdillah, N. (2015). Memahami pentingnya perilaku asertif. Retrieved October 9, 2019 from https://www.kompasiana.com/n471b/5509532ba33311ae4d2e3944/memahamipentingnya-perilaku-asertif\#. Diunduh 9 Oktober 2019.

Bogdan, R. C., \& Biklen, S. K. (1982). Qualitative research for education. Boston: Allyn \& Bacon Inc.

Breitman, P., \& Hatch, C. (2001). How to say no without feeling guilty: Jangan enggan berkata tidak dan ikutilah kata hati anda. Alih bahasa: Agus Riyanto. Editor: Deborah Hutauruk. Jakarta: Erlangga.

Coloroso, B. (2006). Stop bullying. Terjemahan Santi Indra Astuti. Jakarta: Serambi Ilmu Semesta. 
Depdikbud. (2007). Rambu-rambu pelaksanaan bimbingan dan konseling pada jalur pendidikan formal. Jakarta: Direktorat Jenderal PMPTK.

Hamnida, K. (2010). Teori asertif. Retrieved August 18, 2018 from https://jungjera.wordpress.com/tag/teori-asertif/.

Karunia, N. E. (2018). Bullying, Masalah sederhana yang tak bisa dipandang sebelah mata. Retrieved August 3, 2018 from http://www.ubaya.ac.id/2014/content/interview_ detail/85/Bullying--Masalah-Sederhana-Yang-Tak-Bisa-Dipandang-SebelahMata.html.

Kementerian Pendidikan dan Kebudayaan. (2016). Panduan operasional penyelenggaraan bimbingan dan konseling sekolah menengah pertama (SMP). Jakarta: Direktorat Jenderal Guru Dan Tenaga Kependidikan.

Lange, A. J., \& Jackubowski, P. (1978). Responsible assertive behavior: Cognitive bahavior procedurs training. Illionis: Research Press.

Linda. (2019). Lawan rasa takutmu dengan 10 cara menghadapi bully ini. Retrieved October 2, 2018 from https://kamini.id/cara-menghadapi-bully/

Mappiare-AT, Andi. (2013). Tipe-tipe metode riset kualitatif untuk eksplanasi sosial budaya dan bimbingan konseling. Malang: Elang Mas bersama Prodi Bimbingan dan Konseling. Fakultas Ilmu Pendidikan Universitas Negeri Malang.

Puspitasari, D. (2017). 7 penyebab anak-anak melakukan tindakan bullying. Retrieved August 18, 2018 https://www.shopback.co.id/blog/7-penyebab-anak-anak-melakukantindakan-bullying.

Sari, D. K. (2016). Panduan pengembangan keterampilan asertif dengan teknik sosiodrama untuk mencegah perilaku bullying siswa sekolah menengah (Untuk konselor). Malang: Jurusan Bimbingan dan Konseling Fakultas Ilmu Pendidikan Universitas Negeri Malang.

Strorey, K., Slaby, R., \& Adler, M. (2013). The eyes on bullying toolkits. USA: Education Development Center.

Tadjri, I. (2014). Penelitian tindakan bimbingan \& konseling. latihan dan praktik penyusunan proposal. Semarang: Swadaya Manunggal.

Warnaningrum, I. D., \& Na'imah, T. (2016). Perilaku memaafkan pada korban bullying fisik di sekolah menengah pertama. Psycho Idea, 14(1), 41-47.

Winarlin, R., Lasan, B. B., \& Widada, W. (2016). Efektivitas teknik sosiodrama melalui bimbingan kelompok untuk mengurangi perilaku agresif verbal siswa SMP. Jurnal Kajian Bimbingan dan Konseling, 1(2), 68-73. 